ORIGINAL RESEARCH ARTICLE

\title{
Folk herbal medicines used by the Tribals of Bayad taluka in Aravalli District, Gujarat, India. \\ Mukesh M. Patel
}

Department of Biology, Government Science College, Gandhinagar, Gujarat, India.

Received: January 26, 2016; Revised: January 26, 2016; Accepted: February 24, 2016.

\begin{abstract}
Ethnomedicinal field trips were undertaken during 2012-2014 in the villages of Bayad taluka, Aravalli district, Gujarat, for the documentation of folk and herbal medicinal plants used by local people residing in and around forest areas. During field trips firsthand information on traditional uses of wild medicinal plant species was collected from tribal people. The source of information is based on interviews with local Vaidyas, Bhagats, Shepherds and local tribal informants of the area. The study indicated that tribe depends on medicinal flora for curing their various diseases. The study showed that, 24 plant species belonging to 22 genera of 20 Angiosperms families were recorded during field trips in study area.
\end{abstract}

Key words: Ethnomedicine; Tribals; Bayad; Aravall; Gujarat.

\section{Introduction}

Ethnobotany is a multi-disciplinary natural science which deals with human plant relationship. Importance of Ethnobotany has been realized by the mankind by means of various uses of plants in their day to day life science the beginning of life on the earth. During the last half century, Ethnobotany has more and more been recognized as a valid discipline that can play a very material role in the advancement of many aspects of scientific, sociological and historical studies. In the most of the villages, there are usually one/two local practitioners of the traditional medicine, locally known as a 'Bhagat'. These practitioners have acquired the knowledge (mostly oral/non codified) for treating patients, mostly from the elders of the family. The tribal people residing in and around forest areas are still heavily dependent on locally available medicinal flora for curing their ailments. In the most of the tribal villages, there are usually two/three local medicine men of the traditional medicine, locally known as 'Bhagat'. These practitioners have acquired the knowledge (mostly oral / non codified) for treating patients, mostly from the elders of the family. Indigenous medicinal uses in India were recorded by Kirtikar and Basu (1995), the uses of ethnomedicinal by Jain (1991) and in North Gujarat by Bhatt and Sabnis (1987), Punjani (1997, 2006).

The Aravalli district is situated in the north-eastern part of Gujarat State between $23^{\circ} 03^{\prime}-24^{\circ} 30^{\prime} \mathrm{N}$ latitudes, and $72 \circ 42^{\circ}-73$ ॰39' $\mathrm{E}$ longitudes. The area is undulating terrain of Aravalli hillocks. The forest is mainly of Dry Mixed Deciduous type with rich floristic diversity. The predominant scheduled tribe in the area is Bhil, Dungari Garasia, etc.

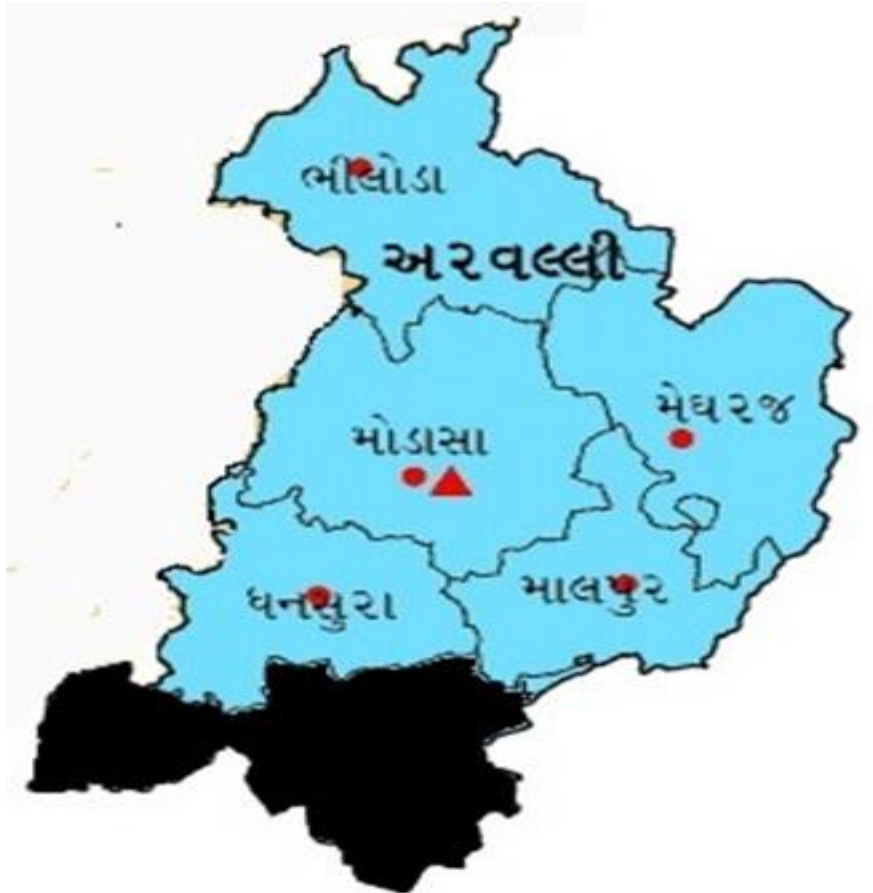

Map showing location of study area

\section{Materials and Methods}

Frequent field trips were arranged during last two years in order to collect information about the traditional knowledge of medicinal plants used by the local people to cure their various diseases. During field trips, the questionnaire, camera and audio video instruments were used to interview and discussion with local informants, bhagats and elder villagers of different localities of the area including men and women both, who were familiar with traditional uses of plants. Indigenous traditional practitioners and some knowledgeable tribal informants were interviewed in the forest and in their homes. The data were recorded on the plants part used, local name(s), process of preparation and mode of administration and dosage. The collected plant specimens were identified using flora (Shah, 1978). The data considered worth mentioning only 
when at least 2 to 3 local healers gave similar answers for the same plant.

\section{Results and Discussion}

Enumeration: In enumeration of plant species is arranged alphabetically.

Alangium salvifolium (L.f.) Wang /
Alangiaceae / 'Ankol'.
Part used: Leaf (Panda \& Padhy, 2008)
Boiled leaves in lukewarm condition are spread over
affected area and bandaged with cotton clothe once
on alternate day to cure swelling.

Anogeissus sericea Brandis / Combretaceae / 'Aendrokh'.

Part used: Leaf

Boiled leaves in lukewarm condition (100 g, approx.) are spread over affected area which was previously applied with ghee/ oil and bandaged with cotton cloth once a day up to two days to get relieve from belly enlargement.

\section{Boswellia serrata Roxb / Burseraceae / 'Salaren'. \\ Part used: Gum (Goel \& Mudgal, 1988) \\ $1 \mathrm{~g}$ fresh gum/resin is dissolved in $100 \mathrm{ml}$ boiled milk and then given orally once to stop chest pain in male patient.}

\section{Butea monosperma (Lam.) Taub / Papilionaceae / 'Khakhro'. \\ Part used: Flower (Jain et al., 2008; Mishra, 2008) Powder of $1 \mathrm{~kg}$ (approx.) flower's which was dried in shade. One teaspoonful powder of dried flowers is given orally once a day at night up to one week to control blood pressure.}

Capparis sepiaria L. / Capparaceae / 'Kanther'. Part used: Root (Jadav, 2009)

Paste of $50 \mathrm{~g}$ root of 'Kanther' [Capparis sepiaria L. (Capparaceae)] and $20 \mathrm{~g}$ seed of 'Kalijiri' [Vernonia anthelmintica (L.) Willd. (Asteraceae)] is applied topically on chicks for once a day up to two days to reduce swelling due to mumps.

\section{Citrullus colocynthis (L.) Schrad / Cucurbitaceae / 'Tundu'. \\ Part used: Root (Kanwar et al., 2006) \\ Paste of fresh/dry root is applied externally over skin eruptions on foot once at night for a week to reduce pain due to heal cracks.}

Dichrostrachys cinerea (L.) W. \& A. / Mimosaceae / 'Medol'.

Part used: Bark (Punjani, 2006)

Paste of bark is applied topically over affected part on the skin for rupturing and fast healing of the boil.
Helicteres isora L. / Sterculiaceae / 'Maradsing'

Part used: Fruit (Katewa \& Galav, 2006; Udayan et. al, 2008)

Filtered fruit mixture is given orally twice a day for 2-3 day to cure diarrhea.

Holoptelea integrifolia (Roxb.) Planch. / Ulmaceae / 'Karji'.

Part used: Leaf (Maheshwari et al., 1986)

Paste of the fresh leaves is applied topically over infected part on the skin to cure ringworm.

Holostemma annularium (Roxb.) K. Schum. / Asclepiadaceae / 'Bhatto'.

Part used: Root (Sudhakar \& Rolla, 1985)

About $5 \mathrm{~cm}$ piece of root is chewed and the juice is swallowed slowly thrice a day for two days to cure cough and cold.

Leptadenia pyrotechnica (Forsk.) Decne. / Asclepiadaceae / 'Khip'.

Part used: Stem (Nagendra \& Abraham, 1983)

Approximately $500 \mathrm{~g}$ younger stem is boiled with 1 ltr water, after cooling the filtrate is kept in a bottle. Two teaspoon filtrate is given orally twice a day up to one month to cure tuberculosis (TB).

Plumbago zeylanica L. / Plumbaginaceae / 'Chitro, Shitri'.

Part used: Root (Silja, et al., 2008)

Paste is prepared from fresh root is applied topically on an infected part once a day for two days to cure ringworm.

Pterocarpus marsupium Roxb.var. acuminatus Prain / Papilionaceae / 'Biyo'.

Part used: Bark (Punjani, 2006)

One teaspoonful powder of bark with cup of water is given orally once a day in the morning up to five days to treat menorrhea.

Syzygium heyneanum Wall. ex W. \& A. / Myrtaceae / 'Makan jambu'.

Part used: Bark (Warrier et al., 1995)

Paste of bark is applied topically over affected part on the skin to cure wound. Bark is must be taken from eastern or western side of plant.

Tephrosia purpurea (L.) Pers. / Papilionaceae / 'Kharhundio'.

Part used: Root (Panda \& Padhy, 2008)

Root is chewed slowly twice a day to cure toothache. The application is repeated, if required.

Tridax procumbens L. / Asteraceae / 'Pardeshi bhangro'

Part used: Whole plant (Ramchandran \& Nair, 1981)

Juice of the plant is filled in the fresh wound to prevent pus formation and for fast healing of the cut and wounds. 
Typha angustata Bory \& Chaub. / Typhaceae / 'Ghabajariu'.

Part used: Fibers (Shah \& Amin, 2005)

Fruit fibers filled in/sprayed over fresh cuts/wounds for fast healing and to prevent septic. Due to this practice flowing of blood stops immediately.

Vernonia anthelmintica (L.) Willd. / Asteraceae / 'Kalijiri'

Part used: Seed (Rajendran et al., 2008)

One teaspoonful seed powder is administered internally with water once in a day in empty stomach to cure ascariasis.

Withania somnifera (L.) Dunal / Solanaceae / 'Ashvagandha'.

Part used: Root (Chauhan \& Pillai, 2003; Ganesan et al., 2006)

One cup of filtrate root decoction is given orally twice a day up to two weeks to cure backache.

Zizyphus mautitiana Lam. / Rhamnaceae / 'Deshi bordi'.

Part used: Leaf

Paste of leaves (chewed in mouth) is applied topically over affected area once a day for two days to cure acne.

\section{Discussion}

The tribal people of Bayad taluka used wild plant species for the treatment of different human ailments like Achne, Ascariasis, Backache, Belly enlargement, Boils, BP, Cough and Cold, Cracks, Diarrhea, Menorrhea, Mumps, Pain, Ringworm, TB, Toothache, Wounds etc. Present investigation showed that in all, the people use 20 different wild medicinal plants for curing various ailments, of which trees were dominant Herbs, Shrubs, Climbers \& Twiners. Out of all 16 families, it is observed that 3 families having 2 or more than 2 plant species whereas, rest of families contribute with only one species each used in the treatment of ailments. For the treatment of various human ailments 10 plant parts are used. Of which Root is used in maximum 6 applications in different diseases. Next to it, Leaf and Bark each used in 4 and 3 applications, hence it holds second and third position in plant parts used. The details of various plant parts used are given in Fig. 1.

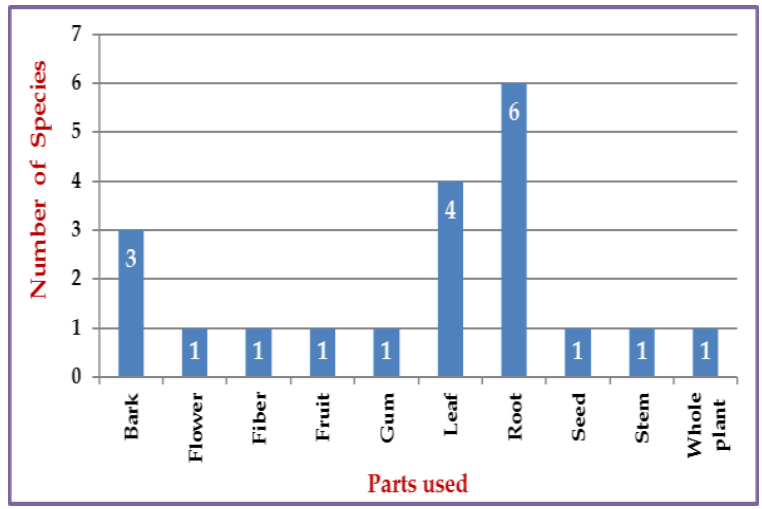

Figure 1: Number of plant species based on plant parts used

\section{Conclusion}

Tribal medicinemen have their own rules and beliefs for extraction of medicinal plant or its parts from nature. In this modern era of science, it has become absolutely necessary to accumulate, to document and to preserve this rich traditional knowledge, which may provide novel drug for curing particular disease. The tribal people of Bayad taluka in Aravalli district have a vast wealth of plants, which are sources of medicinal compounds. Therefore, more concerted efforts are needed for the documentation of all the tribal medicines and their health practices useful in the treatment of different disorders. The above reported ethnomedicinal plants also require a proper chemical, pharmacological experiments and clinical trials for the validation of the traditional claims. It was suggested to document such vital and valuable knowledge for the future generation as this knowledge found to be decline day-to-day. On the other hand, loss of important floral diversity also leads to declining of it. Hence conservation of floral diversity will be important tool to sustain and carry such important knowledge to the future generation.

\section{Acknowledgement}

The first author is highly thankful to all the tribal informants, medicinemen and women and the staff of the Forest Department for their co-operation and help during ethnobotanical field trips by providing the information and company during the field trips in the forest area.

\section{References}

1. Kirtikar, K. R. and Basu, B. D. "Indian Medicinal Plants". Lalit Mohan Basu, Allahabad, India, Vol. I-IV 1984.

2. Jain, S. K. "Dictionary of Indian Folk medicine and Ethnobotany”. Deep publication, New Delhi, 1991.

3. Bhatt, R. P and Sabnis, S. D. "Contribution to the Ethnobotany of Khedbrahma region of North Gujarat”. Journal Econ. Tax. Bot. 9 (1987): 139-145. 
4. Punjani, B. L. "An Ethnobotanical Study of Tribal Areas of District Sabarkantha (Gujarat)". Ph.D. Thesis, Hem. North Gujarat University, Patan, 1997.

5. Shah, G. L. "Flora of Gujarat State". Sardar Patel University Press, Vallabh Vidhyanagar, Vol. I \& II 1978.

6. Tirkey, A. "Some ethnomedicinal plants of familyFabaceae of Chhattisgarh state". Indian J. Traditional Knowledge 5.4 (2006): 551-553.

7. Venkata, R. K, G., Tirupati Reddy and R.R., Venkata Raju. "Herbal remedies for eye infections used by the tribals of Nallamala forests, Andhra Pradesh". Indian J. Traditional Knowledge 9.4 (2010): 765-767.

8. Khan, Mohd Habibullah and Yadava, P. S "Antidiabetic plants used in Thoubal district of Manipur, Northeast India". Indian J. Traditional Knowledge 9.3 (2010): 510-514.

9. Chhetri, D. R. "Ethnomedicinal plants of the khanchendzonga National Park, Sikkim, India". Ethnobotany 17 (2005): 96-103.

10. Panda, T. and Padhy, R. N. "Ethnomedicinal plants used by tribes of Kalahandi district, Orissa". Indian J. Traditional Knowledge 7.2 (2008): 242-249.

11. Chaudhary, M., Datta, Shil, Saniib and Chakraborty, Gouri. "Ethno-medicobotanical studies on Dimasa Kachari of Cachar district, Assam". Ethnobotany 20 (2008): 128-132.

12. Shah, N. C. "Ethno-cosmetics for beauty \& ethnomedicine for skin diseases used in India". Ethnobotany 24 (2012): 4-13.

13. Punjani, B. L and Kumar, V. "Folk medicinal plants used for skin disorders in the tribal pocket of Sabarkantha district, Gujarat". Journal of Natural Remedies 2.1 (2002): 84-87.

14. Jadhav, Dinesh. "Ethno-medicinal survey of Maalgamdi in Ujiain district, Madhya Pradesh, India". Ethnobotany 18 (2006): 157-159.

15. Gupta, Mradu and Shaw, B. P. "Uses of medicinal plants in Panchakarma Ayurvedic therapy". Indian J. Traditional Knowledge 8.3 (2009): 372-378.

16. Jain, A, Katewa, S. S, Galav, P and Nag, A. "Some therapeutic uses of biodiversity among the tribals of Rajasthan". Indian J. Traditional Knowledge 7.2 (2008): 256-262.

17. Mishra, Shakun. "Ethnomedicinal studies of korku tribe, with Gotra names derived from plant names, from Khandwa district in Madhya Pradesh". Ethnobotany 20 (2008): 122-127.

18. Kumar, S and Chauhan, A.K.S. "Less-known medicinal uses of plant species in Keoladeo National Park, Bharatpur, Rajasthan". Ethnobotany 18 (2006): 153-166.
19. Upadhyay, Ruchi and Singh, Jaswant. "Ethnomedicinal uses of plants from Tikri forest of Gonda District (U.P.)". Ethnobotany 17 (2005): 167-170.

20. Nadanakunjidam, S and Abirami, S. "Comparative study of traditional medical knowledge of Pondicherry and Karaikal regions in Union Territory of Pondicherry". Ethnobotany 17 (2005): 112-117.

21. Punjani, B. L. "Ethno-medicobotanical study of Kathodi tribe of Sabarkantha in Gujarat". Ethnobotany 18 (2006): 135-138.

22. Muhammad, Ishtiaq, $\mathrm{Ch}$ and Khan, M. A. "An Ethnomedicinal inventory of plants used for planning and sex diseases in Samahni valley, Pakistan". Indian J. Traditional Knowledge 7.2 (2008): 277-283.

23. Chakraborty, M. K and Bhattacharjee, A. "Some common ethnomedicinal uses for various diseases in Purulia district, West Bengal”. Indian J. Traditional Knowledge 5.4 (2006):554-558.

24. Arya, K. R and Agarwal, S. C. "Conservation of threatened medicinal and folklore plants through cultivation in Uttaranchal state". Ethnobotany 18 (2006): 77-86.

25. Verma, Saroj and Chauhan, N. S. "Studies on ethnomedico-botany of Kunihar Forest Division, district Solan (H.P.)". Ethnobotany 18 (2006): 160-165.

26. Bhogaonkar, P. Y and Kadam, V. N. "Some local reproductive health practices in Umarkhed of Yavatmal district in Maharashtra, India”. Ethnobotany, 18 (2006): 107-113.

27. Bhatt, V. P and Vashishtha, D. P. "Indigenous plants in traditional healthcare system in Kedarnath valley of western Himalaya". Indian J. Traditional Knowledge 7.2 (2008): 300-310,

28. Das, AjitKumar, Dutta, B. K. and Sharma, G. D. "Medicinal plants used by different tribes of Chachar district, Assam". Indian J. Traditional Knowledge 7.3 (2008): 446-454

29. Mahato, R. B and Chaudhary, Ram, P. "Ethnomedicinal plants of Palpa District, Nepal". Ethnobotany 17 (2005): 152-163.

30. Kumar, Shailendra and Chauhan, A.K.S "Ethnomedicinal plants used by Gujjars in Bharatpur, Rajasthan”. Ethnobotany 24 (2012): 119-122.

31. Naidu, B.V.A., Ramarao, Reddi, T.V.V., Seetharami and Prasanthi, S. "Folk herbal remedies for rheumatoid arthritis in Shrikakulam district of Andhra Pradesh". Ethnobotany 20 (2008): 76-79.

\section{Cite this article as:}

Mukesh M. Patel Folk herbal medicines used by the Tribals of Bayad taluka in Aravalli District, Gujarat. Annals of Plant Sciences 5.2 (2016): 12721275 . 